\title{
DILEMA PELEMBAGAAN PARTAI GOLONGAN KARYA (GOLKAR) DI TINGKAT LOKAL: FENOMENA POLITIK KLAN
}

\author{
Muhammad Ridha T.R \\ Peneliti Pada Pusat Studi Politik dan Keamanan (PSPK) Universitas \\ Padjadjaran, Dan Mahasiswa Magister Politik dan Pemerintahan \\ Fisipol Universitas Gadjah Mada Yogyakarta
}

Email:m.ridhotaufik@gmail.com

\begin{abstract}
ABSTRAK
Tulisan ini dimulai dari keresahan penulis mengenai fenomena politik klan yang banyak bermunculan di Indonesia, justru ketika Indonesia pada kenyataanyya sedang dalam proses demokratisasi. Harus diakui bahwa, fenomena politik klan membangun sebuah paradoks dalam proses demokratisasi di Indonesia. Namun pada tulisan ini, penulis mencoba untuk fokus kepada keterkaitan antara politik klan dengan institusionalisasi partai politik, dengan melihat partai Golkar sebagai sebuah arena dimana politik klan dan institusionalisasi partai bertemu.

Pertemuan antara politik klan dan institusionaisasi partai ini dapat terjadi di Partai Golkar, karena disamping keberhasilan partai Golkar untuk bertahan dalam gelombang demokratisasi dan transformasinya dari organisasi penyokong rezim otoriter Orde Baru menjadi partai politik yang demokratis, dimana keberhasilan itu bisa dikatakan akibat dari adanya institusionalisasi partai yang baik, justru di tingkat daerah atau dalam istilah Partai Golkar, Dewan Pimpinan Daerah (DPD), banyak sekali terjadi praktik politik klan yang dari sudut pandang konsep Institusionalisasi partai adalah sebuah paradoks.

Kesimpulan dari tulisan ini adalah, politik klan dapat muncul dalam proses demokratisasi internal partai Golkar akibat dari, pertama, demokrasi di Indonesia yang membutuhkan biaya sangat mahal yang membuat partai membutuhkan dukungan finansial yang mumpuni dengan memanfaatkan kader-kader di daerah yang tergolong kepada local strongman yang memiliki akses kepada modal ekonomi dan juga modal sosial. Kedua, adanya ketidaksiapan publik menghadapi perubahan yang dibawa oleh demokratisasi, ketika mereka sudah terbiasa selama 32 tahun berada dalam baying-bayang rezim otoriter Orde Baru untuk memilih seseorang dalam pemilu berdasarkan hubungan patron-klien.
\end{abstract}

Kata kunci: Demokratisasi, Politik Klan, Institusionalisasi Partai, Partai Golkar

160 CosmoGov, Vol. 2 No. 1, April 2016 


\begin{abstract}
This paper begins with the author anxiety about the phenomena of political clan that many implicated in Indonesia, while Indonesia is in fact in the process of democratization. That is to say, a political clan is building a paradox in the democratization process in Indonesia. In this paper, the authors focus on the link between political clans with the institutionalization of the party, with notice of the Golkar Party, as the arena where the linkages between party institutionalization and political clan are meet.

This is because, amid the success of Golkar Party to endure the brunt of democratization and transformation of organizations wich supporting the authoritarian New Order regime, into a democratic political party, which is considered to be achieved success because of the institutionalization of the party is quite good, there is a phenomenon in which the Golkar Party organization structure at the local level, or in terms of organization Golkar is the Regional Leadership Council (DPD), there are many practices of political clans, when seen from party institutionalization variables is a paradox.

The conclusion of this paper is, clan politics can be implicated in the internal democratization of the party is the excess of, first, the high cost of democracy in Indonesia, which makes the party requires considerable financial support and also the emergence of local strong man who have access to social capital and economic capital. Second, the public unpreparedness in the face of a democratic system where the people's choice was based on patron-client relationships, which are embedded in and away during the 32 years of the New Order regime in power.
\end{abstract}

Keywords: Democratization, Political Clan, Party Institutionalization, the Golkar Party

\section{LATAR BELAKANG}

Studi ini dilakukan bermula dari kegelisahan penulis mengenai proses demokratisasi yang terjadi di Indonesia, khususnya di ranah lokal yang menjadi tempat bergejalanya berbagai paradoks, dimana proses demokratisasi justru membawa banyak bangunan baru di tingkat lokal yang tidak sesuai dengan prinsip- prinsip demokrasi, salah satunya adalah fenomena politik klan. Politik klan ini penulis pahami banyak menggejala akibat dari demokratisasi semu yang terjadi di Indonesia, yang memunculkan banyak elit lokal baru yang berkuasa dan dapat menjadi gambaran umum bagi keberhasilan atau kegagalan proses demokratisasi itu sendiri. 
Demokratisasi merupakan gerakan mainstream yang tengah melanda hampir semua Negara di dunia. Demokratisasi diartikan sebagai sebuah proses yang dilalui oleh sebuah Negara yang dipimpin oleh pemerintahan yang otoriter atau oligarkis, menuju pemerint ahan yang demokratis dalam rangka mencapai kehidupan masyarakatnya yang lebih layak ${ }^{164}$. Demokrasi menjadi pilihan banyak Negara di dunia karena, tidak seperti bentuk lain dari sebuah sistem pemerintahan, demokrasi memungkinkan warga negara untuk mengejar dengan bebas apa yang mereka harapkan untuk kehidupan pribadi mereka sendiri lewat pemilu yang kompetitif dan bebas serta diselenggarakan secara teratur ${ }^{165}$.

Teori mengenai demokratisasi, mengalami polarisasi mainstream. Polar pertama mengaktualisasikan teori demokratisasi di negara yang dianggap berhasil melakukan transisi. Polar kedua dilakukan di negara yang dianggap gagal. Kegagalan yang dimaksud disini menurut Darren Hawkins (2001), bukan berarti adanya transisi dari demokrasi ke otoritarian, sebagai opposite dari transisi otoritarian menuju demokrasi yang merupakan konsep utama demokratisasi, namun kegagalan disini berarti ketidak hadiran aspekaspek demokrasi dalam berlangsungnya kehidupan negara tersebut ${ }^{166}$. Demokratisasi juga membuka ruang dan peluang bagi dinamika politik lokal di Indonesia. Maka dari itu, tulisan ini mencoba melihat kasus demokratisasi di Indonesia, dalam aras lokal, yang dengan kemunculan politik klan di dalamnya, dilihat sebagai kesemuan dan paradoks dalam demokratisasinya. Demokratisasi di Indonesia tidak bisa dikatakan gagal karena aspek demokrasi sebagian hadir, tidak pula dikatakan sangat berhasil karena ada beberapa aspek yang juga absen, dimana kealphaan ini membidani lahirnya politik klan dalam demokrasi di Indonesia.

Politik klan secara mainstream juga dipandang sebagai sesuatu yang telah terbentuk sebagai institusi politik informal untuk kemudian mendapatkan legitimasi dari rakyat dan bertransformasi menjadi institusi politik formal melalui demokrasi procedural yang mengandaikan demokrasi terbentuk melalui pemilihan

164. Shin, Doh Chull \& Junhan Lee. (2003). Democratization and Its Consequences. Social Indicators Research, Vol. 62/63

165. Ibid, hal. 2

166. Hawkins, Darren. (2001). Democratization Theory and Nontransitions: Insights from Cuba. Comparative Politics, Vol. 33, No. 4 (Jul., 2001), pp. 441-461 The City University of New York. 
umum semata. Artinya, politik klan secara mainstream ini dipandang sebagai ruang independen yang terbentuk sebelum adanya demokrasi procedural. Namun di Indonesia, politik klan ini menemukan cara tersendiri untuk mengeksistensikan dirinya. Politik klan di beberapa daerah di Indonesia, dapat dilihat sebagai sebuah entitas yang muncul justru melalui adanya demokrasi struktural.

Melihat demokratisasi di Indonesia, runtuhnya rezim otoriter Suharto pada tahun 1998 dapat dikatakan sebagai langkah awal Indonesia dalam memasuki arus demokratisasi. Perubahan sistem pemerintahan otoritarian menjadi demokrasi ini membawa harapan akan terciptanya tatanan social, ekonomi, dan politik yang lebih baik. Pelaksanaan pemilu presiden dan tructural di tingkat pusat maupun pemilihan kepala daerah secara langsung seolah menjadi bukti realisasi demokratisasi dan terlaksananya demokrasi di Indonesia. Namun dalam kenyataannya, pelaksanaan demokrasi di Indonesia menyisakan banyak masalah bagi demokrasi itu sendiri. Demokrasi procedural yang cenderung lebih dikedepankan, justru memunculkan dan mempertegas adanya paradoks dalam demokrasi yang diterapkan di Indonesia.
Tulisan ini bermaksud untuk memaparkan mengenai paradoks dalam perjalanan proses demokratisasi di Indonesia. Disatu sisi, demokrasi menjamin kebebasan setiap individu untuk secara luas berpartisipasi dalam sebuah kontestasi politik dan seolah mengharamkan politik klan yang dianggap bisa mengamputasi akses partisipasi dalam kontestasi tersebut bagi orang lain, namun di sisi lain kebebasan dan kompetisi yang digelar demi demokrasi justru mengukuhkan tokoh-tokoh klan sebagai pemenang dalam kontestasi kekuasaan. Artinya, dengan demokrasi, politik klan bukan hanya mendapatkan kesempatan untuk bertahan, melainkan juga mendapatkan basis legitimasinya.

Politik klan bergulir melalui budaya tradisional yang kerjanya didasarkan pada keturunan, hubungan sanak keluarga. Dalam kasus tertentu, politik klan bahkan dilangsungkan melalui pertalian darah yang dibuatbuat (fiktif), dan ini merupakan sebuah tantangan yang sangat serius bagi proses pembangunan politik modern. Klan adalah sebuah organisasi sosial tradisional yang "bersaing untuk kekuasaan agar dapat menetapkan peraturan" dan mempengaruhi berbagai tuntutan dan konflik sosial ${ }^{167}$.

167. Collins, Kathleen. (2004). The Logic Of Clan Politics Evidence from the Central Asian Trajectories. World Politics 56.2. Hal. 2 
Dalam proses demokratisasi dan penyelenggaraan pemerintahan modern, politik klan merupakan sebuah struktur. Buku The Logic Of Clan Politics Evidence from the Central Asian Trajectories, yang ditulis Kathleen Collins ${ }^{168}$ menunjukkan hal itu. Lebih dari itu, adanya struktur dan tataran budaya traditional ini telah menghimpun dan membiasakan praktek-praktek politik informal, termasuk pengelolaan jejaring klan. Lebih dari itu, tatanan ini memungkinkan kekuasaan yang ada dapat bertahan begitu lama, bahkan menjadikan demokrasi menjadi alat untuk mempertahakan "durability" dari kekuasaannya. Pertanyaannya adalah, bagaimana sebuah klan juga memanfaatkan patronase, jaringan keluarga untuk melanggengkan kekuasaannya tersebut? Dalam studinya tersebut, Collins menunjukkan bahwa politik klan ini menjadikan pemerintahan berwatak otoritarian. Hanya saja, tulisan tersebut tidak menjelaskan bagaimana sebuah klan politik dapat terbentuk, serta efek dari adanya klan politik ini dalam penyelenggaraan pemerintahan yang demokratis.
Sementara itu, Oxford Analytica Daily Brief Service Dalam studinya di Indonesia yang berjudul Local Clans Define Investment Climate, menjelaskan bahwa fenomena politik klan berjalan beriringan ketimpangan sosial-ekonomi. Di masyarakat dimana orang-orang memiliki kesempatan yang berbada untuk terjun dalam dunia politik dan memenangkan sebuah pemilu, klan menjadi sumberdaya penting. Dalam situasi ini, beberapa kelompok masyarakat memiliki akses politik lebih luas, kalau bukan tructu penuh terhadap masyarakat. Pada akhirnya, kelompok masyarakat mayoritas yang memiliki akses terbatas untuk ikut serta dalam sebuah kontestasi politik, hanya dijadikan sebagai lumbung suara oleh klan politik tertentu untuk melegitimasi dan membuat tahan lama kekuasaan klan/keluarga nya tersebut ${ }^{169}$.

Hampir serupa dengan kedua tulisan diatas, studi mengenai politik klan Kahar Mudzakkar di Sulawesi Selatan yang dilakukan oleh Haryanto, menitik beratkan aspek kebudayaan dan ideologis yang ada di masyarakat dalam membantu kemunculan politik klan tersebut. Haryanto (2014) dalam

168. Ibid,

169. Diolah dan diparaphrasekan dari tulisan Anonim. (2013). Indonesia: Local clans define investment climate. Oxford Analytica Daily Brief Service. 
tulisannya, menyimpulkan bahwa politik klan Kahar Mudzakkar dapat bertranformasi dari aktor politik informal menjadi aktor politik formal adalah karena adanya sebuah nilai, baik itu nilai kebudayaan maupun nilai ideologis yang sudah tertanam di masyarakat sejak lama mengenai Kahar Muzakkar, sehingga memudahkan keturunannya menggunakan hal tersebut untuk memobilisasi dukungan untuk kemudian bertransformasi menjadi aktor formal politik, melalui pemilihan kepala daerah ${ }^{170}$.

Dari ketiga tulisan tersebut, penulis mengambil sebuah tarikan benang merah bahwa fenomena politik klan yang terjadi di Negara demokratis, merupakan sebuah fenomena dimana sekelompok elit politik dari institusi organisasi informal yang sudah terbentuk sejak lama yang memiliki sejarah panjang dalam masyarakat yang dapat membentuk nilai yang seolah melekat pada klan tersebut, sehingga orang-orang yang berkaitan dengan klan tersebut yang didasarkan pada kedekatan keluarga, pertalian darah, dan ikatan kekeluargaan memanfaatkan demokrasi procedural sebagai bagian dari proses demok- ratisasi untuk mendapatkan legitimasi atas kekuasaan dari klan nya tersebut.

Munculnya bangunan politik klan sebagai sebuah paradoks dalam demokratisasi di Indonesia, khususnya di aras lokal tentunya secara tidak langsung berdampak pula pada bangunan-bangunan lain yang sudah terbentuk sebelumnya akibat pross demokratisasi ini. Salah satunya adalah partai politik, yang banyak ahli menganggap fitur dasar demokrasi menjadi sebuah sistem yang dapat dilembagakan melalui sebuah proses dimana warga memilih kader mereka untuk jabatan publik melalui pemilihan umum dan lawan politik mereka sebagai oposisi, dimana hal ini menjelaskan pembangunan dan kinerja partai politik merupakan bagian integral untuk memahami proses demokrasi secara keseluruhan ${ }^{171}$. Artinya ketika kita berbicara mengenai demokratisasi yakni sebuah proses transisi menuju demokrasi yang terjadi di sebuah negara, maka kita tidak bisa tidak harus melihat partai politik sebagai sebuah bangunan penting untuk melihat kinerja dan proses demokrasi yang terjadi.

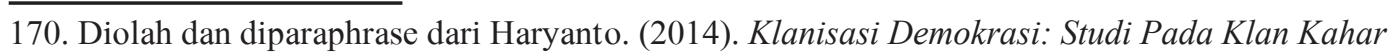
Mudzakkar di Sulawesi Selatan. Tesis Master, Magister Politik dan Pemerintahan Universitas Gadjah Mada, tidak dipublikasikan.

171. Wellhofer, E. Spencer and Timothy M. Hennessey. (1974). Political Party Development: Institutionalization, Leadership Recruitment, and Behavior. American Journal of Political Science, Vol. 18, No. 1 (Feb., 1974), pp. 135-165 
Peran partai politik juga sangat besar dalam mewujudkan salah satu aspek penting yang harus ada dalam sebuah sistem demokrasi, yakni menyelenggarakan pemilihan berkala untuk menciptakan sebuah sistem perwakilan yang dapat membawa pendalaman bagi demokrasi ${ }^{9}$. Pendalaman demokrasi membutuhkan langkah lebih lanjut untuk memperkuat kewarganegaraan dan demokratisasi negara. Penguatan kewarganegaraan berarti mengubah warga dari subyek pasif dalam hubungan tergantung dengan politisi tertentu atau pihak menjadi warga negara yang aktif yang tahu bahwa mereka memiliki hak dan sah dapat mengajukan tuntutan pada pemerintah. Salah satu cara untuk membedakan kewarganegaraan diperkuat dalam praktek adalah untuk melihat apakah jumlah warga yang secara teratur dan langsung berpartisipasi dalam pengambilan keputusan meningkat pemerintah, yang merupakan tujuan utama dari percobaan ini. Cara kedua adalah memeriksa perubahan dalam kekuatan aktor sosial kolektif, atau masyarakat sipil, untuk melihat apakah asosiasi yang ada menjadi lebih politis atau tidak.
Demokratisasi negara juga melibatkan dua dimensi: transparansi dan struktural. Meningkatkan transparansi mensyaratkan bahwa musyawarah dan tindakan negara yang lebih umum, dengan harapan bahwa korupsi dan clientelism surut jika tidak bisa hilang. Sementara responsiveness dapat dipahami dalam hal seberapa baik negara memberikan pada tunt utan yang berasal dari program-program partisipasi baru ${ }^{10}$.

Kebanyakan setuju bahwa program partisipasi sukses membutuhkan kemitraan antara aktor negara dan masyarakat sipil. Mereka yang fokus pada satu saja kehilangan poin penting lainnya yang dibuat oleh pengamat awal bahwa keduanya diperlukan dan bahwa sementara politisi progresif yang terpilih ke kantor lokal tampaknya "memainkan peran yang menentukan ... ini sendiri bisa menjadi hasil dari mobilisasi sebelumnya oleh organisasi struktur. ${ }^{11}$ "

Maka pernyataan ini tentunya mendasari pula setiap hal yang ada dalam sebuah proses demokrasi, dipengaruhi dan mempengaruhi bangunan dari partai politik itu sendiri. Berbicara

172. Goldfrank, Benjamin. (2007). The Politics of Deepening Local Democracy: Decentralization, Party Institutionalization, and Participation. Comparative Politics, Vol. 39, No. 2 (Jan., 2007) hal 147

173. Ibid, hal 148

174. Hilda Herzer and Pedro Pirez, "Municipal Government and Popular Participation in Latin America," Environment and Urbanization, 3 (April 1991), dalam 
mengenai kaitan antara partai politik dan demokratisasi, Goldfrank (2007) menyebutkan bahwa sebuah partai politik yang dapat mendukung terciptanya demokratisasi dan nilainilai demokrasi yang tertanam cukup dalam, harus memenuhi syarat tertentu, dan syarat yang paling utama adalah partai politik tersebut harus terlembagakan

terinstitusionalisasi ${ }^{175}$.

Pada intinya, demokrasi berarti pemerintah yang memperlakukan warga negara yang sama dan bahwa warga negara memiliki hak yang sama untuk berpartisipasi dalam pemerin$\operatorname{tahan}^{176}$. Dari pandangan ini, penulis kemudian menganalisa bagaimana sebuah partai politik bisa mendukung dan membawa arah demokrasi menjadi lebih baik jika partai politik ini justru yang menjadi wadah berkembangnya bangunan politik klan yang menjadi paradoks dalam demokratisasi itu sendiri. Partai politik menjadi sarana untuk politik klan mendapatkan legitimasinya dari masyarakat melalui sebuah kontestasi politik dalam pemilihan umum, maka para aktor politik klan ini membangun bangunan klan politiknya didalam sebuah partai politik sebagai kendaraan untuk memasuki dan mengakses pemilihan umum tersebut. Padahal politik klan ini kemudian bisa dianggap sebagai bangunan yang menghalangi hak orang lain untuk dapat berpartisipasi dalam proses demokrasi. Politik klan disisi lain, membantu partai politik meraih dukungan suara dalam pemilihan umum. Para aktor politik klan di Indonesia, kebanyakan merupakan orang kuat lokal yang memiliki sumber daya dan modalitas baik itu modal ekonomi maupun modal sosial yang sangat tinggi sehingga mudah untuk mendapatkan suara dari rakyat.

Dari latar belakang tersebut diatas, pertanyaan yang muncul dalam rencana penelitian ini adalah, Apakah dengan kondisi sebuah partai yang dipimpin oleh suatu klan, dapat dikatakan sebagai sebuah partai yang sudah terinstitusionalisasi? Ukuran pelembagaan suatu partai dapat dilihat dari berbagai variable sebagai indikatornya, yang banyak dikemukakan oleh berbagai peneliti yang memiliki fokus pada kajian mengenai partai politik. Namun, dalam tulisan ini, satu hal yang akan disoroti lebih dalam dibandingkan variable-variabel lainnya yaitu proses demokrasi internal yang terjadi di dalam partai politik itu sendiri, khususnya dalam proses pergantian dan pemilihan pemimpin atau kandidat oleh partai politik.

175. Op.Cit., Goldfrank hal. 150

176. Ibid, hal. 150 


\section{Pelembagaan Partai: Sebuah Konsep}

Partai politik pada hakikatnya adalah sebuah suprastruktur yang harus dimiliki sebuah sistem pemerintahan agar dapat dikatakan sebagai sistem pemerintahan yang demokratis. Untuk memaksimalkan fungsinya sebagi bangunan yang mendukung pemerintahan yang demokratis, sebuah partai haruslah terlembagakan. Pelembagaan partai politik yang dimaksud adalah, merupakan proses pemantapan sikap dan perilaku partai politik yang terpola atau sistemik sehingga terbeentuk suatu budaya politik yang mendukung prinsip-prinsip dasar demokrasi ${ }^{177}$. Kemudian, Randall dan Svasand (2002) juga mengatakan bahwa agar secara sistem semakin tersebut ternilai sebagai sistem yang demokratis, maka partai politik dan sistem kepartaian yang ada haruslah terinstitusionalisasi ${ }^{178}$.

Randall dan Svasand (2002) dalam tulisannya mengenai institusionalisasi partai politik dan sistem kepartaian mengemukakan pelembagaan partai politik adalah, proses pemantapan partai politik baik secara structural dalam rangka mempolakan perilaku maupun secara kultural dalam mempolakan sikap atau budaya ${ }^{179}$. Sementara Untuk Huntington, 'Pelembagaan adalah proses dimana organisasi dan prosedur mendapatkan nilai dan stabilitas' ${ }^{180}$. Ia mengidentifikasi empat dimensi pelembagaan: adaptasi, kompleksitas, otonomi dan koherensi. Adaptasi sebagian dapat disimpulkan dari umur panjang, termasuk kemampuan untuk bertahan hidup generasi pertama para pemimpin, tetapi juga mencakup adaptasi fungsional, Contohnya dalam hal kelompok yang diwakili, atau dari oposisi terhadap pemerintah. Kompleksitas organisasi diukur dengan jumlah sub-unit. Otonomi mengacu pada derajat diferensiasi dari 'kelompok sosial lain dan metode perilaku'. Koherensi berkaitan dengan tingkat tructura dalam organisasi pada batas-batas fungsional dan prosedur

177. Imansyah, Teguh. (2012). Regulasi partai politik dalam mewujudkan penguatan peran dan fungsi kelembagaan partai politik. Jurnal Rechtsvinding, vol 1 no.3, Jakarta

178. Randall, Vicky and Svåsand, Lars. 2002. "Party Institutionalization in New Democracies". Party Politics. London: SAGE Publication

179. Ibid. hal 16 Dengan terjemahan asli the process by wich the party become established in terms of both integrated patterns on behaviour and of attitude and culture

180. Huntington, Samuel P. (2004). Tertib Politik Pada Masyarakat Yang Sedang Berubah. Jakarta: Raja Grafindo hal. 12 
untuk menyelesaikan perselisihan yang timbul dalam batas-batas tersebut. Meskipun dalam teori otonomi dan koherensi adalah karakteristik independen, dalam prakteknya mereka cenderung saling tergantung antara satu dengan lainnya.

Pelembagaan partai merujuk pada empat dimensi sistem institusionalisasi partai yang dikembangkan Mainwaring dan Scully (1995): Pertama, stabilitas kompetisi partai. Kompetisi partai yang tidak disertai institusionalisasi akan mempertinggi angka volatility dalam pemilu. Kedua, kedalaman akar partai dalam masyarakat. Partai memiliki wilayah pendukung utama yang tidak berubah setiap pemilu dan mempunyai struktur yang mengikat. Akar partai dalam masyarakat ditentukan oleh program dan tructur yang jelas dan dapat diterima masyarakat serta menyangkut hubungan antara partai dan pemilihnya. Lemahnya hubungan struktur antara partai dan pemilih menjadi salah satu komponen yang memperlemah pengakaran partai di masyarakat. Ketiga, adanya legitimasi aktor-aktor politik terhadap partai. Mereka melihat partai sebagai sebah bagian yang penting dalam demokrasi. Keempat, partai dianggap terlembaga apabila organisasi kepartaian bukan merupakan subordinasi dari kepentingan pemimpin - pemimpinnya. Proses pelembagaan partai akan sangat dibatasi selama partai masih menjadi struktural personal dari pemimpinnya ${ }^{181}$.

Namun demikian dalam melihat pelembagaan partai politik ini, terdapat banyak sekali perbedaan pandangan dari peneliti-peneliti terdahulu, seperti Huntington, Levitsky, dan Janda mengenai di mana kualitas tertentu masing-masing yang seharusnya dimiliki oleh partai itu sendiri, atau apa jenis sistem partai yang paling kondusif untuk mendukung pemerintahan yang demokratis. Maka selanjutnya, Randall mengkombinasikan syarat-syarat agar terciptanya partai yang terlembagaa dari pendapat Huntington, Levitsky, dan Janda tersebut.

Randall dan Svasand (2002) kemudian mensimplifikasi pendapatpendapat para ahli mengenai partai politik tersebut, menjadi kesatuan variable yang saling berkaitan satu sama lainnya. Proses pelembagaan ini dibagi menjadi dua aspek yaitu aspek internal-eksternal, dan aspek tructuralkultural. Apabila kedua aspek ini

181. Mainwaring, Scott and T. Scully. (1995). Building Democratic Institutions: Party Systems in Latin America. Stanford, CA: Stanford University Press. 
dipersilangkan maka akan dihasilkan sebuah struktur empat sel, yaitu (1) derajat kesisteman (systemnes) sebagai hasil persilangan aspek internal dengan tructural. (2) derajat identitas nilai (value infusion) suatu partai sebagai hasil persilangan aspek internal dengan kultural. (3) derajat otonomi suatu partai dalam pembuatan keputusan (decisional autonomy) sebagai hasil persilangan aspek eksternal dan struktural. (4) derajat pengetahuan atau citra publik (reification) sebagai hasil persilangan aspek eksternal dengan kultural ${ }^{182}$. Yang kemudian 4 poin tersebut harus pula dilihat kembali dari berbagai dimensi yakni asal-usul partai, kepemimpinan partai, faksionalisasi, klientelisme, dukungan eksternal dan jaringan-jaringan lainnya, serta, melihat isu-isu seperti asal-usul partai, sumber daya, kepemimpinan partai, faksionalisme, klientelisme dan sponsor eksternal dan hubungan lainnya ${ }^{183}$.

Variable yang digunakan untuk melihat pelembagaan partai politik menurut Randall dan Svasand ini, dapat dilihat dalam diagram berikut ini,
Tabel 1. Variabel Pelembagaan Politik

\begin{tabular}{|c|c|c|}
\hline & Internal & External \\
\hline Structural & Systemness & $\begin{array}{l}\text { Decisional } \\
\text { Autonomy }\end{array}$ \\
\hline Attitudinal & $\begin{array}{c}\text { Value } \\
\text { Infusion }\end{array}$ & Reification \\
\hline
\end{tabular}

Sumber: Randall dan Svasand (2002)

Dari diagram tersebut, dapat dilihat bagaimana pelembagaan partai politik harus dilihat dari aspek internal maupun eksternal yang berarti, kaitan partai politik dengan demokratisasi bukan hanya termanifestasi dalam kegiatan eksternal partai politik, namun juga harus tercermin dalam sistem yang dimiliki internal partai dalam segala hal. Artinya pemilihan kepemimpinan, keputusan internal, penentuan arah kebijakan yang sifatnya internal harus pula mencerminkan nilai-nilai demokrasi yang ada. Maka ketika suatu partai dalam aspek internalnya tidak menunjukkan nilainilai demokrasi maka partai tersebut belum bisa disebut sebagi partai politik yang sudah terlembagakan.

Selanjutnya, Institusionalisasi atau pelembagaan partai juga

182. Randall, Vicky and Svåsand, Lars. 2002. "Party Institutionalization in New Democracies". Party Politics. London: SAGE Publication

183. Wellhofer, E. Spencer and Timothy M. Hennessey. (1974). Political Party Development: Institutionalization, Leadership Recruitment, and Behavior. American Journal of Political Science, Vol. 18, No. 1 (Feb., 1974), pp. 135-165, 
ditentukan oleh profesionalisme dan pengelolaan partai. Tidak hanya ketika menjelang pemilu, tetapi juga menyangkut rutinitas kegiatan partai. Pengelolaan dan profesionalisme tersebut terdiri dari beberapa aspek penting kehidupan partai. Termasuk dalam hal ini adalah pembangunan ideologi dan kebijakan, aturan main, kekuasaan dan latar belakang sosial anggota partai dan pemimpinnya, rekruitmen dan candidate yang duduk di legislatif, serta proses marketing dari partai tersebut. Keprofesionalan dari para staff partai yang menjalankan fungsinya sehari-hari menjadi elemen penting dalam pelaksanaan aspekaspek di atas.

Paul Webb dan Robin Kolodny mencatat tentang lingkup bagaimana partai yang profesional bekerja. Dibutuhkan staff yang profesional dalam menjalankan partai. Kampanye tidak hanya dilakukan ketika pemilu berlangsung, tetapi juga dilakukan secara berkesinambungan untuk membentuk dan mengartikulasi posisi konstituen. Efeknya, beberapa partai harus menjalankan pembagian fungsifungsi tertentu. Beberapa diantaranya adalah, rekruitmen dan nominasi candidate untuk pemilihan, melakukan penelitian terhadap kebijakan dan mempelajari strategi lawan politik dalam pemilu, pembangunan kebijakan, pengolaan dana untuk memenangkan pemilu, publikasi dan marketing kebijakan partai, mengukur opini publik dan mempelajari mobilisasi dukungan publik.
Pandangan lain mengenai pelembagaan partai politik dalam sebuah sistem demkrasi, dikemukakan oleh Wellhofer and Hennessey (1974) yang berasumsi dasar bahwa perilaku partai politik dalam sistem politik yang demokratis adalah sebagian besar ditentukan oleh kombinasi tertentu dari proses kelembagaan, pola rekrutmen kepemimpinan, preferensi karir kepemimpinan, dan tingkat perubahan aktivitas warga dan kecanggihan yang partai diharapkan untuk merespon melalui pemilihan berkala. Sebagai tindak lanjut dari asumsi ini, keduanya berusaha untuk menentukan kondisi di mana berbagai elemen berinteraksi untuk mempengaruhi proses pembangunan partai politik. Dalam tulisan ini kedua penulis berkonsentrasi pada dua hal yaitu, pelembagaan dan rekrut men dan perilaku kepemimpinan.

Secara umum, Wellhofer dan Hennessey mengungkapkan bahwa banyak faktor-faktoryang menentukan perilaku partai politik dimanipulasi oleh para pemimpin untuk mempertahankan organisasi dan posisi mereka di dalamnya. Mengingat pertimbangan-pertimbangan ini, pola rekrutmen kepemimpinan akan cenderung untuk mencerminkan tujuan organisasi pada setiap tahap tertentu pembangunan.

Rekrutmen kepemimpinan dalam sebuah proses organisasi yang dijelaskan di atas akan tercermin dalam pola rekrutmen kepemimpinan: yaitu, sebagai organisasi yang berpindah dari satu tahap ke tahap lainnya, jenis 
kepemimpinan yang berbeda direkrut, maka Wellhofer dan Hennessey dalam tulisannya ini mencoba untuk mengukur perekrutan kepemimpinan dengan menggunakan tiga indikator utama: spesifisitas, turn over (perputaran) kepemimipinan, dan tipe kepemimpinan dominan. Dua yang pertama mengacu pada proses struktural, sedangkan yang ketiga adalah lebih dinamis dan melibatkan pengalaman partai sebelumnya para pemimpin dan peran ini bermain dalam perhitungan mereka atas dan terhadap persyaratan organisasi pada setiap tahap tertentu pembangunan.

Indikator pertama, spesifisitas, mengacu pada sejauh mana penghuni posting partai nasional adalah kelompok yang berbeda dalam partai, dan diukur dengan lamanya waktu mereka telah dalam organisasi sebelum mencapai pos kepemimpinan tingkat atas. Tumover mengacu pada tingkat penerimaan anggota baru untuk posting partai nasional. Pada tahap awal, perputaran diperkirakan akan cepat, karena tujuan partai adalah dalam proses yang ditetapkan dan tidak ada pola kemajuan sangat jelas. Namun seiring waktu, tingkat pergantian harus tajam menurun, sebagai prioritas organisasi menjadi lebih jelas dan struktur sosial internal lebih mapan. Perkembangan ini memungkinkan calon untuk lebih akurat menghitung kemungkinan mereka berhasil mengambil jabatan partai. Insentif dominan organisasi yang berhubungan dengan jenis kepemimpinan tertentu. Di sini Wellhofer dan Hennessey (1974), mempertimbangkan tiga jenis pemimpin dibedakan oleh jumlah pengalaman kepemimpinan dalam subunit partai sebelum mendapatkan posisi partai di tingkat nasional. Para pemula telah memegang jabatan di setiap subunit, telah mengadakan jabatan secara transisional di satu atau dua subunit, sedangkan para pejabat partai tingkat nasional telah melalui tingkatan jabatan di semua tiga subunit.

Wellhoffer dan Hennsessey dalam tulisannya ini berpendapat bahwa pengalaman memegang jabatan sebelumnya merupakan indikator yang baik dari insentif dihargai oleh calon tersebut; semakin berjenjang jabatan seorang pemimpin, semakin ia akan berkomitmen untuk organisasi. Artinya dalam sebuah kepemimpinan partai politik, seharusnya menurut Wellhofer dan Hennessey, ada sebuah jenjang karir sebelum akhirnya menuju pada puncak jabatan di sebuah partai. Hal ini untuk menunjukkan bahwa partai politik tersebut dalam memilih pemimpin, selain bersifat demokratis (melalui mekanisme musyawarah partai) juga memilih kader terbaik yang muncul bukan secara instan melainkan sudah melalui tahapantahapan sebelumnya. Sebaliknya, jika tidak melakukan hal tersebut, akan megakibatkan banyak perdebatan yang bisa menyebabkan konflik internal akibat adanya status quo dari segelintir orang di internal partai 
politik. Hal ini tentu saja sangat berpengaruh kepada derajat pelembagaan sebuah partai, yang sebelum mempengaruhi masyarakat agar memberikan dan mempercayakan suaranya kepada prtai tersebut, harus terlebih dahulu memperhatikan aspek internal partai.

Tulian selanjutnya mengenai pelembagaan partai adalah, penelitian yang dilakukan oleh Scott Mainwaring dan Timothy Scully mengenai bangunan lembaga demokratis di Amerika Latin. Dalam tulisannya ini, Mainwairing dan Scully berpendapat bahwa penting untuk mempelajari pelembagaan sistem partai sebagai sarana untuk memahami politik di negara demokrasi baru-baru ini.. Dalam rangka untuk membedakan tingkat institusionalisasi dalam sistem tertentu, Mainwaring dan Scully merekomendasikan memeriksa empat fitur dari sistem kepartaian: tingkat stabilitas dalam persaingan antarpartai; tingkat akar partai di masyarakat; legitimasi bahwa partaipartai dan pemilihan umum yang dianggap memiliki dalam menentukan siapa yang memerintah; dan, terakhir, soliditas partai sebagai organisasi.

Menurut Mainwaring dan Scully, sistem partai dilembagakan (sistem dengan persaingan antar-partai regularized dan pihak ditandai dengan akar yang kuat dalam masyarakat, legitimasi, dan organisasi yang sangat maju) biasanya ditemukan di negaranegara demokrasi industri maju, meskipun mereka telah pula tumbuh di beberapa negara demokrasi baru. Sistem yang telah dilembagakan memberikan stabilitas dan struktur politik yang membuat sistem beroperasi dengan prediksi yang lebih besar. Dalam sistem yang dilembagakan, partai politik mampu memenuhi salah satu fungsi yang paling penting demokratis mereka: memungkinkan pemilih untuk meminta pertanggungjawaban pemerintah. Sebaliknya, dalam sistem yang relatif tidak terlembagakan, partai tidak memberikan struktur yang mendasari untuk melakukan operasi politik dengan cara melembagakan sistem kepartaian ${ }^{184}$.

Hal ini akan menyebabkan partaipartai datang dan pergi dari satu pemilihan umum ke yang berikutnya. Akar sosial partai yang lemah, yang mengarah ke ketidakstabilan sebagai pemilih mengambang dari satu partai kepada pihak lain. Partai dalam sistem yang relatif tidak terlembagakan sering lemah sebagai organisasi, dan

184. Mainwaring, Scott and T. Scully. (1995). Building Democratic Institutions: Party Systems in Latin America. Stanford, CA: Stanford University Press. 
banyak karakteristik personalistik display (di mana pemimpin individual lebih penting daripada partai itu sendiri) dan kurangnya disiplin internal dan profesionalisme. Partai yang dilembagakan secara lemah membuat pemerintahan sulit dalam beberapa cara. Ketika partai cenderung naik dan turun sangat cepat, itu menjadi sulit untuk menahan politisi akuntabel karena kurangnya hubungan antara partai dan kebijakan khusus diberlakukan. Tanpa akar sosial, partai sering buruk selaras dengan kepentingan konstituen, dan, sebagai hasilnya, mereka mengembangkan kebijakan dan memerintah dengan cara bercerai dari kehendak rakyat. Organisasi partai yang lemah, terutama yang kurang disiplin, membuat mengembangkan dan memberikan program legislatif tantangan berat. Dalam sistem kepartaian yang lemah dalam pelembagaan, legitimasi juga merupakan hal yang sering dipertanyakan, meningkatkan kemungkinan bahwa oposisi pemerintah mungkin menggoyang atau bahkan membatalkan sistem. Ini akan menjadi naif untuk mengharapkan sistem kepartaian sangat dilembagakan dan pola suara yang stabil dalam pemerintahan yang telah rusak bebas dari kediktatoran yang kuat baru-baru ini dimiliki dalam sistem di Indonesia.

\section{Keberhasilan Partai Golkar \\ Bertahan di Tengah Tekanan \\ Demokratisasi: Kekuatan \\ Pelembagaan Partai}

Proses demokratisasi di Indonesia ditandai dengan runtuhnya rezim orde baru untuk kemudian tergantikan oleh massa reformasi yang mengusung sistem demokrasi. Reformasi politik 1998 ini, kemudian membalikkan situasi politik dan mempengaruhi konstelasi partai politik di Indonesia. Di era orde baru, otomatis sistem kepartaian di Indonesia merupakan sistem dwipartai yang diisi oleh PDI (Partai Demokrasi Indonesia) dan PPP (Partai Persatuan Pembangunan), ditambah satu golongan karya sebagai mesin politik pendukung rezim. Dalam sistem kepartaian seperti ini, otomatis kemenangan dalam pemilu selalu didominasi oleh kemenangan telak dari Golongan Karya atau yang biasa disebut Golkar. Dominasi ini dapat terjadi, karena Golkar sepenuhnya merupakan mesin politik utama pendukung rezim otoriter yang di pimpin oleh Soeharto yang juga didukung oleh kekuatan militer dan pejabat birokrasi serta pegawai negeri sipil yang dalam setiap pemilu diarahkan untuk memilih Golkar.

Jatuhnya Soeharto dan rezim Orde baru yang menjadi patron politik Golkar, menyebabkan organisasi politik terbesar ini, seakan kehilangan pegangan dan haluan politiknya. Kemudian, berbagai tekanan politik mulai dialamatkan kepada Golkar, 
terutama karena Golkar dianggap sebagai penyebab utama krisis. Hal ini kemudian memunculkan banyak prediksi dari berbagai kalangan baik politisi maupun para ahli politik bahwa Golkar kemudian tidak akan mampu bertahan hidup dalam masa reformasi dan akan menyusul runtuhnya kekuasaan Soeharto dengan rezim Orde Baru-nya ${ }^{185}$. Penentangan dan anjuran agar Golkar dibubarkan datang bertubi-tubi baik dari kalangan politisi dari partai yang besebrangan dengan Golkar maupun dari masyarakat. Imej yang melekat pada Golkar sebagai organisasi dan mesin politik pendukung rezim orde baru yang selalu menyebar teror dalam setiap pemilihan umum agar masyarakat memilihnya, seharusnya mendukung semua prediksi dan asumsi yang dikemukakan oleh para tokoh dan akademisi ini.

Namun kemudian, semua prediksi, tekanan, dan penentangan terhadap Golkar ini seolah hanya menjadi pepesan kosong karena kemudian Golkar bisa bertransformasi menjadi Partai Golkar untuk mengikuti pemilihan umum tahun 1999, dan berhasil mengumpulkan suara terbanyak kedua setelah PDIP yang dipimpin oleh Megawati, yang ketika itu muncul sebagai partai yang menjadi simbol partai politik demokratis yang memimpin reformasi sebagai manifesto perlawanan terhadap orde baru bersama Partai Amanat Nasional (PAN) yang dipimpin Amien Rais, juga Partai Kebangkitan Bangsa (PKB) yang dipimpin oleh KH. Abdurrahman Wahid.

Menurut Akbar Tandjung $(2006)^{186}$, berdasarkan data-data yang diperolehnya dalam penelitiannya tersebut, menganalisa bahwa Golkar dapat bertahan karena Golkar mendayagunakan kelembagaan yang telah terbangun selama rezim Orde Baru berkuasa, yaitu berupa struktur dan jaringan organisasi yang jauh mencakup seluruh wilayah nasional, maupun nilai-nilai yang berhasil dibangun dan menjadi jatidiri serta perekat bagi soliditas organisasi. Namun kemudian, hal ini $\mathrm{m}$ belum dianggap cukup untuk membuat Golkar bertahan, maka Golkar dalam menghadapi reformasi kemudian melakukan adaptasi dengan merombak struktur maupun kultur organsasi sehingga sejalan dengan nilai-nilai reformasi.

185. Lihat Ringakasan Disertasi Doktoral Akbar Tandjung di Universitas Gadjah Mada, (2006). Partai Golkar Dalam Pergolakan Politik Era Reformasi Tantangan dan Respons, yang kemudian diterbitkan menjadi sebuah buku yang berjudul The Golkar Ways.

186. Ibid, hal 15 
Adaptasi yang dilakukan oleh Golkar agar sejalan dengan nilai-nilai demokrasi diantaranya adalah dengan langsung melakukan Munaslub (Musyawarah Nasional Luar Biasa) yang merupakan forum tertinggi partai untuk kemudian memilih ketua baru, menghapuskan dewan pembina, dan menentukan arah strategi dalam menghadapi kemandirian (Tandjung, 2006), yang harus dilaksanakan oleh Golkar akibat adanya keharusan untuk bersikap netral dalam pemilu bagi militer dan birokrat, yang selama ini menjadi lumbung suara utama Golkar.

Keberhasilan partai Golkar untuk bertahan dalam transisi demokrasi dari rezim otoriter orde baru ke orde reformasi, dan keberhasilannya bertransformasi menjadi sebuah partai politik demokratis salah satunya, menurut analisa penulis merupakan salah satu bukti bahwa Golkar telah terlembaga cukup baik. Hal ini dapat terlihat dari aspek Systemness, yang dipahami sebagai the increasing scope, density and regularity of the interactions that constitute the party as a structure. Regularity implies a degree of routinization, and the development of prevalent conventions guiding behaviour (Randall dan Svasand, 2002), dimana Partai Golkar sudah merombak total organisasinya pasca reformasi agar sejalan dengan nilai-nilai demokrasi, yang menjadi pijakan dasar dari Partai Golkar dalam menentukan arah dan kebijakan organisasi. Systemness ini juga dilihat dari organizational development that has typically been understood in terms of the elaboration of a formalized structure and the building of mass membership (Randall and Svasand, 2002), yang juga bisa dilihat dalam structural dan keanggotaan Partai Golkar yang secara legal ditetapkan melalui munaslub, serta keanggotaan yang luas melalui organisasiorganisasi sayap partai yang berasal adri berbagai kalangan.

Kemudian dari aspek value infusion (Randall dan Svasand, 2002), yang dapat dilihat sebagai the extent to which party actors and supporters (whether or not falling into a more formalized category of membership) acquire an identification with and commitment to the party which transcend more instrumental or selfinterested incentives for involvement, juga diperlihatkan oleh anggota, kader, dan simpatisan Partai Golkar dengan memunculkan nilai pluralitas dalam setiap aspek, sehingga memunculkan Partai Golkar sebagai catch-all party (Tandjung, 2006), yang menempatkan Partai Golkar menjadi partai tengah, diantara dikotomi yang terjadi antara nasionalis dan islam.

Sementara dari aspek reification (Randall dan Svasand, 2002), yang dilihat sebagai the extent to which the party's existence is established in the public imagination, Partai Golkar juga sudah memilikinya, khususnya dikalangan pegawai negeri sipil dan keluarga militer, bahwa mereka sudah sepatutnya sebagai abdi negara 
memilih Golkar dalam setiaap pemilu. Hal ini dapat terjadi karena penanaman dan doktrin yang cukup lama hingga berpuluh tahun yang dilakukan oleh Orde Baru, sehingga sulit untuk menghilangkan doktrin-doktrin yang sudah tertanam tersebut.

Kemudian salah satu aspek yang membuat Partai Golkar sebagai partai yang terlembagakan adalah, Golkar merupakan salah satu partai yang sangat stabil, untuk hadir dalam setiap pemilihan umum di Indonesia pasca reformasi dan mendapatkan suara selalu lebih dari 15\%. Meskipun pasca runtuhnya Orde Baru, raihan suara partai Golkar yang pada awalnya selalu diatas $50 \%$ dan bisa dikatakan turun drastic, namun konsistensinya dalam setiap pemilu membuat Partai Golkar bertahan.

Tabel 2. Perolehan Suara

Pemilu 1999

\begin{tabular}{|c|c|c|c|c|}
\hline No. & Nama Partai & Suara & Kursi Tanpa SA ") & Kursi Dengan SA") \\
\hline & PDIP & 35.689 .073 & 153 & 154 \\
\hline 2 & Golkar & 23.741 .749 & 120 & 120 \\
\hline 3 & PPP & $\mid 1.329 .905$ & 58 & 59 \\
\hline 4 & PKB & |3.336.982 & $\$ 1$ & \$1 \\
\hline 5 & PAN & 7.528 .956 & 34 & 35 \\
\hline 6 & PBB & 2049,708 & 13 & 13 \\
\hline 7 & Partai Keadilan & 1.436 .565 & 7 & 6 \\
\hline 8 & PKP & 1.065 .686 & 4 & 6 \\
\hline 9 & PNU & 679,179 & 5 & 3 \\
\hline 10 & POKB & 550,846 & 5 & 3 \\
\hline 11 & PBI & 364,291 & 1 & \\
\hline 12 & $\mathrm{PDI}$ & 345,72 & 2 & 2 \\
\hline 13 & PP & 655,052 & 1 & \\
\hline 14 & PDR & 427,854 & 1 & \\
\hline 15 & PSII & 375,92 & 1 & \\
\hline 16 & PNII front Marthenis & 365,176 & 1 & \\
\hline 17 & PNI Massa Marheen & 345,629 & 1 & \\
\hline 18 & IPKI & 328,654 & 1 & I \\
\hline
\end{tabular}

\begin{tabular}{|c|c|c|c|c|}
\hline 19 & PKU & 300,064 & I & \\
\hline 20 & Masyumi & 456,718 & 1 & \\
\hline 21 & PKD & 216,675 & & \\
\hline 22 & PNI Supeni & 377,137 & & \\
\hline 23 & Krisna & 369,719 & & \\
\hline 24 & PartaiKAMI & 289,489 & & \\
\hline 25 & PUI & 269,309 & & \\
\hline 26 & PAY & 213,979 & & \\
\hline 27 & Partai Republik & 328.564 & & \\
\hline 28 & Partai MKGR & 204,204 & & \\
\hline 29 & PIB & 192.712 & & \\
\hline 30 & Partai SUNI & 180,167 & & \\
\hline 31 & $P C D$ & 168,087 & & \\
\hline 32 & PSIII 1905 & 152,82 & & \\
\hline 33 & Masyumi Baru & 152.589 & & \\
\hline 34 & PNBI & 149,136 & & \\
\hline 35 & PUDI & 140,98 & & \\
\hline 36 & PBN & 140,98 & & \\
\hline 37 & PKM & 104,385 & & \\
\hline 38 & PND & 96,984 & & \\
\hline 39 & PADI & 85,838 & & \\
\hline 40 & PRD & 78,73 & & \\
\hline 41 & PPI & 63,934 & & \\
\hline 42 & PID & 62,901 & & \\
\hline 43 & Murbs & 62,006 & & \\
\hline 44 & SPSI & 61,105 & & \\
\hline 45 & PUMI & 49,839 & & \\
\hline 46 & PSP & 49,807 & & \\
\hline 47 & PARI & 54,79 & & \\
\hline 48 & PILAR & 40,517 & & \\
\hline & JUMLAH & 105.786.661 & 462 & 462 \\
\hline
\end{tabular}

Sumber: www.kpu.go.id

Tabel 3. Perolehan Suara Pemilu 2004

\begin{tabular}{|c|c|c|c|c|}
\hline No. & Nama Partai & Jumlah Suara & "Asuara & Kursi \\
\hline & Partai Nasional Indonesia Merhaenisme & 906,739 & 0,80 & \\
\hline 2 & Partei Burruh Sosiel Demokrat & 634,515 & 0,56 & 0 \\
\hline 3 & Partai Buten Bintang & 2.965 .040 & 2,62 & \\
\hline 4 & Partai Merdeka & 839,705 & 0,74 & 0 \\
\hline 5 & Partai Persetuan Penberngunan & 9.226 .444 & 8,16 & 58 \\
\hline 6 & Partai Persatuan Demokrasi Kebangsazn & 1.310 .207 & 1,16 & 4 \\
\hline 7 & Partai Pertimpunan Indonesia Baru & 669,835 & 0,59 & \\
\hline 8 & Partai Nasional Benteng Kemerdekaan & 1.228 .497 & 1,09 & 0 \\
\hline 9 & Partai Demokrat & 8.437 .868 & 7,46 & 55 \\
\hline 10 & Partai Keadlin dean Persaturn Indonesia & 1.420 .085 & 1,26 & 1 \\
\hline & Partai Penegzk Demokrasi Indonesia & 844,48 & 0,75 & \\
\hline
\end{tabular}




\begin{tabular}{|c|c|c|c|c|}
\hline 12 & Partei Persatuan Neholatul Ummah Indonesia & 890,98 & 0,79 & 0 \\
\hline 13 & PartaiAmanat Nasional & 7.255 .331 & 6.41 & 53 \\
\hline 14 & Partai Karya Peduli Bangsa & 2394.651 & 2,12 & 2 \\
\hline 15 & Partai Kebangkitan Bangsa & 12.002885 & 10,61 & 52 \\
\hline 16 & Partei Keadlen Sejahtera & 8.149 .457 & 7,20 & 45 \\
\hline 17 & Partai Bintang Reformasi & 2.94 .529 & 2,60 & 14 \\
\hline 18 & Partei Demokrasi indonesia Perjuangen & 20.710 .006 & 18,31 & 109 \\
\hline 19 & Partio Damai Sejhtera & 2.424 .319 & 2,14 & 13 \\
\hline 20 & Partai Golongen Karya & 24.461 .104 & 21,62 & 128 \\
\hline 21 & Partie Patriot Pancesila & 1.178 .738 & 1,04 & \\
\hline 22 & Partai Sarikat Indonesia & 677,259 & 0,60 & 0 \\
\hline 23 & Partai Persetuan Daerah & 656,473 & 0,58 & \\
\hline 24 & Parti Pelopor & 896,603 & 0,79 & 3 \\
\hline & TOTAL & $\mid 13.125 .750$ & 100,00 & 550 \\
\hline
\end{tabular}

Sumber: www.kpu.go.id

Tabel 4. Perolehan Suara Pemilu 2009

\begin{tabular}{|c|c|c|c|c|}
\hline No. & Nama Partai & Suara & Persentase & Kursi \\
\hline 1 & Partai Hati Nurani Rakyat & 3.925 .620 & 3,77 & 17 \\
\hline 2 & Partai Karya Peduli Bangsa & 1.461.375 & 1,40 & 0 \\
\hline 3 & Partai Pengussha Dan Pekeria Indonesia & 745.965 & 0,72 & 0 \\
\hline 4 & Partai Peduli Rakyat Nasional & 1.260 .950 & 1,21 & 0 \\
\hline 5 & Partai Gerakan Indonesia Raya & 4.642.795| & 4,46 & 26 \\
\hline 6 & Partai Barisan Nasional & 760.712 & 0,73 & \\
\hline 7 & Partai Keadilan Dan Persatuan Indonesia & 936.133 & 0,90 & 0 \\
\hline 8 & Partai Keadilan Sejahtera & 8.204.946 & 7,89 & 57 \\
\hline 9 & PartaiAmanat Nassional & 6.273 .462 & 6,03 & 46 \\
\hline 10 & Partai Periuangan Indonesia Baru & 198.803 & 0,19 & 0 \\
\hline II & Partai Kedaulaten & 438.030 & 0,42 & 0 \\
\hline 12 & Partai Persatuan Daerah & 553.299 & 0,53 & 0 \\
\hline 13 & Partai Kebangkitan Bangsa & 5.146 .302 & 4,95 & 28 \\
\hline 14 & Partai Pemuda Indonesia & 415.563 & 0,40 & 0 \\
\hline 15 & Partai Nasional Indonesia Marhaenisme & 317.433 & 0,31 & 0 \\
\hline 16 & Partai Demokrasi Pembaruan & 896.959 & 0,86 & 0 \\
\hline 17 & Partai Karya Perjuangen & 351.571 & 0.34 & 0 \\
\hline 18 & Partai Matahari Bangsa & 415.294 & 0,40 & 0 \\
\hline 19 & Partai Penezak Demokrasi Indonesia & |39.988 | & 0,13 & 0 \\
\hline 20 & Partai Demokrasi Kebangsaan & 671.356 & 0,65 & 0 \\
\hline 21 & Partai Republika Nusentara & 631.814 & 0,61 & 0 \\
\hline 22 & Partai Pelopor & 345.092 & 0,33 & 0 \\
\hline 23 & Partai Golongan Karya & 15.031.497 & $\mid 4,45$ & 106 \\
\hline 24 & Partai Persatuan Pembangunan & 5.544 .332 & 5,33 & 38 \\
\hline 25 & Partai Damai Sejahtera & 1.522 .032 & 1,46 & 0 \\
\hline 26 & $\begin{array}{l}\text { Partai Nasional Benteng Kerakyzan } \\
\text { Indonesia }\end{array}$ & 468.856 & 0,45 & \\
\hline 27 & Partai Bulan Bintang & 1.864.642 & 1,79 & 0 \\
\hline 28 & Partai Demokrasi Indonesia Periunangan & 14.576 .388 & 14,01 & 94 \\
\hline 29 & Partai Bintang Reformasi & 1.264.150 & 1,21 & \\
\hline 30 & Partai Patriot & 547.798 & 0.53 & 0 \\
\hline & Partai Demok & 21.655 .295 & 208 & \\
\hline
\end{tabular}

\begin{tabular}{|l|l|r|r|r|}
\hline 32 & Partai Kasih Demokrasi Indonesia & 325.771 & 0,31 & 0 \\
\hline 33 & Partai Indonesia Sejahtera & 321.019 & 0,31 & 0 \\
\hline 34 & Partai Kebangkitan Nassional Ulama & 1.527 .509 & 1,47 & 0 \\
\hline 41 & Partai Merdeka & 111.609 & 0,11 & 0 \\
\hline 42 & Partai Nahdlatul Ummah Indonesia & 146.831 & 0,14 & 0 \\
\hline 43 & Partai Sarikat Indonesia & 141.558 & 0,14 & 0 \\
\hline 44 & Partai Buruh & 265.369 & 0,26 & 0 \\
\hline \multicolumn{2}{|c|}{ TOTAL SUARA } & 104.048 .118 & 100,00 & $\mathbf{5 6 0}$ \\
\hline
\end{tabular}

Sumber: www.kpu.go.id

Table perolehan suara dari mulai pemilu tahun 1999 hingga 2014 diatas, memperlihatkan konsistensi Partai Golkar dalam meraih suara, meskipun turun naik namun tidak terlalu signfikan, yang berbeda dengan partai lain yang tingkat fluktuatifnya sangat tinggi. Hal ini kemudian yang di sebut Mainwairing dan Scully (1995) sebagai partai politik yang terlembagakan dengan konsisten mendapatkan raihan suara sehingga tidak mudah terlempar dan tersisih dari satu pemilu ke pemilu lain.

\section{Dilema Pelembagaan Partai Golkar di Tingkat Lokal: Fenomena Politik Klan}

Keberhasilan Partai Golkar dalam mempertahankan eksistensinya dari partai politik pendukung rezim otoriter yang kemudian bertransformasi menjadi partai yang hadir dalam sebuah sistem demokrasi yang sangat bertolak belakang dengan rezim sebelumnya, yang bisa saja membuatnya ikut hancur lebur bersama lengsernya rezim orde baru, membuktikan bahwa Partai Golkar dalam beberapa hal sudah sangat terlembagakan. Konsistensi suara dari 
satu pemilu ke pemilu lain, bahkan sempat menjadi pemenang pemilu pasca reformasi semakin menasbihkan pelembagaan partai Golkar ini. Namun kemudian, pandangan-pandangan mengenai pelembagaan partai Golkar tersebut kemudian digugat oleh beberapa fenomena yang ditemukan didalam internal partai, khususnya dalam memilih pemimpin partai di tingkat lokal.

Contoh paling mutakhir keterlibatan Partai Golkar dalam pembentukan politik klan, yang mengarah pada politik dinasti adalah bagaimana Partai Golkar dijadikan sebagai alat bagi keluarga H. Chasan, untuk mendapatkan kekuasaan di Provinsi Banten melalui Gubernurnya yakni Ratu Atut Chosiyah. Belum lagi di daerah-daerah tingkat kabupaten/kota yang juga dikuasai oleh keluarga dan kerabat dekat dari sang Gubernur, banyak didukung oleh Partai Golkar sebagai pengusung.

Contoh lain yang mencolok mata adalah bagaimana tokoh Partai Golkar di Jawa Barat $H$. Irianto MS Syafiuddin, atau yang sering dikenal dengan panggilan kang Yance, membangun klan bukan hanya di pemerintahan namun juga di internal Partai Golkar. Irianto MS Syafiuddin atau kang Yance adalah seorang politikus dari Partai Golongan Karya yang kini menjabat sebagai Ketua DPD Partai Golkar Provinsi Jawa Barat. Sebelumnya, Yance merupakan Ketua DPD II Partai Golkar Kabupaten
Indramayu sekaligus menjabat sebagai Bupati Indramayu selama 2 periode berturut-turut. Setelah masa jabatannya habis, Yance kemudian meneruskan karirnya ke tingkat provinsi, dan meninggalkan jabatan Ketua DPD II Golkar Indramayu kepada anaknya yakni Daniel Muttaqie, serta jabatan Bupati Indramayu kepada Istrinya yakni Hj. Anna Sophanah. Dan masih banyak lagi, contoh-contoh lain yang memperlihatkan kaitan antara Partai Golkar dengan praktik politik klan di tingkat lokal.

Hal ini tentunya menunjukkan sebuah paradoks dalam pelembagaan Partai Golkar, khususnya dilihat dari demokrasi internalnya yang terkait dengan Systemness dalam konsepsi pelembagaan partai Randall dan Svasand (2002). Analisa-analisa diatas yang menyebutkan bahwa Partai golkar merupakan partai yang sudah terlembaga dengan baik yang memang diikuti dengan bukti-bukti empiris yang menguatkan analisa tersebut, kemudian seolah luruh setelah melihat fenomena yang ada dalam internal Partai Golkar di tingkat daerah.

Politik klan sendiri merupakan paradoks dalam demokratisasi seperti yang sudah dijelaskan sebelumnya, dimana dalam demokrasi nilai equality yakni kesamaan hak dan kewajiban semua masyarakat untuk dapat ikut serta dalam pemilihan umum. Namun kemudian politik klan ini muncul seolah mengkebiri kesempatan orang 
lain untuk mengakses pemilihan umum. Penulis mencoba untuk menganalisa fenomena politik klan yang kemudian justru didukung oleh sebuah partai politik yang seharusnya menjadi bangunan utama dalam mendukung dan mengarahkan demokrasi menjadi lebih baik.

Penyebab dukungan Partai Golkar terhadap praktik politik klan ini adalah yang pertama, karena mahalnya demokrasi di Indonesia maka partai-partai politik di Indonesia membutuhkan sumber pembiayaan agar dapat bertahan dalam kontestasi politik di Indonesia. Partai Golkar yang pada awalnya disokong oleh rezim dalam segala hal termasuk pembiayaan, pasca reformasi sokongan dana tersebut hilang dan dengan terpaksa mencari sumber dana lain yang bisa membiayai operasional partai. Hal ini dimanfaatkan oleh para orang kuat lokal, yang sebelumnya memang sudah punya kedekatan sejarah dengan partai Golkar sebagai asset di daerah yang dipelihara oleh Soeharto, untuk digunakan sebagai alat dalam mencapai kepentingankepentingan oligarki elit tersebut ${ }^{187}$.
Penyebab yang kedua menurut penulis adalah, kesiapan yang rendah dari masyarakat untuk menerima sistem demokrasi, yang dalam demokrasi suara rakyat merupakan keputusan tertinggi dalam mengambil semua keputusan. Namun rakyat belum menyadari ini, dan termanifestasi dalam setiap pemilihan umum, masyarakat dalam memilih masih terhubung dengan hubungan patronklien, yang memposisikan diri mereka sebagai klien yang akan manut pada patron-nya karena telah diberi imbalan sesuatu. Inilah yang kemudian Partai Golkar, dalam dilemanya agar tetap bisa meraih suaranya dan bertahan ditengah terjangan demokratisasi yang melanda, mendukung para orang kuat lokal sebagai predatory broker politik yang memiliki control monopolistic terhadap kekuatan coersive dan sumber daya ekonomi dalam wilayah territorial mereka ${ }^{188}$.

\section{Konklusi}

Dilema yang dihadapi oleh partai politik di Indonesia, dalam hal ini khusus menyoroti Partai Golkar, dalam melembagakan dirinya adalah,

187. Dwipayana, AAGN Ari. (2009). Demokrasi Biaya Tinggi Dimensi Ekonomi dalam Proses Demokrasi Elektoral di Indonesia Pasca Orde Baru. Jurnal Ilmu Sosial dan Ilmu Politik (JSP), vol. 12 no.3 pp. 257-390, Fisipol UGM, Jogjakarta.

188. Ibid, hal. 260

$180 \mid$ Cosmogov, Vol. 2 No. 1, April 2016 
untuk bertahan dalam sistem demokrasi di Indonesia yang secara kultural masyarakatnya masih mengutamakan hubungan patronklien, yang kemudian juga menyebabkan mahalnya demokrasi di Indonesia, menjadikan partai politik dihadapkan pada berbagai pilihan yang rumit. Inti dari terlembaganya sebuah partai adalah, bagaimana partai politik tersebut bisa bertahan dari pemilu satu ke pemilu lainnya dengan cara mendapatkan legitimasi dan suara rakyat. Maka Pilihan partai Golkar di daerah untuk mendukung terciptanya politik klan, adalah bentuk pragmatisme politik dari sebuah organisasi, dimana dalam mengikuti pemilu di Indonesia yang sangat mahal, membutuhkan kucuran dana yang tidak sedikit. Maka untuk tetap bertahan, dengan mendapatkan suara dari masyarakat agar menjadi partai yang terlembaga, partai Golkar dengan sangat terpaksa dijadikan alat bagi para elit lokal untuk mencapai kepentingan oligarkinya, dengan salah satunya membangun politik klan di internal partai mereka sendiri.

\section{DAFTAR PUSTAKA}

Anonim. (2013). Indonesia: Local clans define investment climate. Oxford Analytica Daily Brief Service. Diakses dari Proquest Journal pada tanggal 29 Desember 2015

Dwipayana, AAGN Ari. (2009). Demokrasi Biaya Tinggi Dimensi
Ekonomi dalam Proses Demokrasi Elektoral di Indonesia Pasca Orde Baru. Jurnal Ilmu Sosial dan Ilmu Politik (JSP), vol. 12 no.3 pp. 257-390, Fisipol UGM, Jogjakarta.

Collins, Kathleen. (2004). The Logic Of Clan Politics Evidence from the Central Asian Trajectories. World Politics 56.2. Diakses dari Proquest Journal pada tanggal 29 Desember 2015

Goldfrank, Benjamin. (2007). The Politics of Deepening Local Democracy: Decentralization, Party Institutionalization, and Participation. Comparative Politics, Vol. 39, No. 2 (Jan., 2007), pp. 147-168, diakses dari JSTOR pada tanggal 3 Juli 2015.

Haryanto. (2014). Klanisasi Demokrasi: Studi Pada Klan Kahar Mudzakkar di Sulawesi Selatan. Tesis Master, Magister Politik dan Pemerintahan Universitas Gadjah Mada, tidak dipublikasikan.

Hawkins, Darren. (2001). Democratization Theory and Nontransitions: Insights from Cuba. Comparative Politics, Vol. 33, No. 4 (Jul., 2001), pp. 441-461 The City University of New York. Huntington, Samuel P. (2004). Tertib Politik Pada Masyarakat Yang Sedang Berubah. Jakarta: Raja Grafindo

Imansyah, Teguh. (2012). Regulasi partai politik dalam mewujudkan penguatan peran dan fungsi kelembagaan partai politik. 
Jurnal Rechtsvinding, vol 1 no.3, Jakarta

Mainwaring, Scott dan Mariano Torcal. (2006). Party System Institutionalization and Party System Theory After the Third Wave of Democratization, dalam Katz, Richard. S dan William Crotty (editor). Hand Book of Party Politics, London: Sage, hlm 206-207

Mainwaring, Scott and T. Scully. (1995). Building Democratic Institutions: Party Systems in Latin America. Stanford, CA: Stanford University Press.

Shin, Doh Chull \& Junhan Lee. (2003). Democratization and Its Consequences. Social Indicators Research, Vol. 62/63

Randall, Vicky and Svåsand, Lars. 2002. "Party Institutionalization in New Democracies". Party Politics. London: SAGE Publication
Webb, Paul and Robin Kolodny. (2006). Professional Staff in Political Parties, dalam Katz, Richard. S dan William Crotty (eds). Hand Book of Party Politics, London: Sage pp.337338

Wellhofer, E. Spencer and Timothy M. Hennessey. (1974). Political Party Development: Institutionalization, Leadership Recruitment, and Behavior. American Journal of Political Science, Vol. 18, No. 1 (Feb., 1974), pp. 135-165, diakses dari JSTOR pada tanggal 3 Juli 2015

www.kpu.go.id

www.poltracking.com

www.ore.exeter.ac.uk/repository/ bitstream/handle/10036/3637/ NoorF.pd 